\title{
Az alapvető jogokat sértő elhelyezési körülmények miatti kártalanítás új szabályairól
}

\section{BODA ZOLTÁN ${ }^{1}$ - NAGY ANTAL ${ }^{2}$}

Véleményem szerint a jogalkotó nem gondolt bele abba, hogy ha valóban elöáll az a helyzet, hogy teljesen megszünnek a büntetés-végrehajtási (bv.) intézetek túlzsúfoltsági körülményei, akkor a következókkel kell szembesülni: a kérelmezők az egyéb elhelyezési körülményeik miatti sérelmek okozta személyiségi jogaik megsértése miatt igényeik pénzbeli kompenzálására irányuló érvényesitésétôl teljesen el lesznek zárva, a bírósághoz fordulás joga kizáródik. „Faramuci” helyzetbe kerülnek tehát a fogvatartottak, mert sem a Bv. tv. szerinti kártalanitási eljárásban, sem pedig a Pp.-n, illetve Ptk.-n alapuló személyiségi jogok megsértése iránt inditott perben érdemi jogorvoslatra nem biztos, hogy számithatnak. Ez pedig korántsem biztos, hogy „kiállna egy EJEB elötti próbát", hiszen jogállami keretek között elképzelhetetlen a számonkérhetöség lehetöségének kvázi el nem ismerése.

Kulcsszavak: kártalanítás, túlzsúfoltság, személyiségi jogok, polgári per, új szabályok

\section{On New Rules of Compensation for Accommodation Conditions Violating Fundamental Rights}

In my opinion, the legislator did not take into account that if the situation of overcrowding in penitentiary institutions does indeed disappear completely, the following issues will have to be faced: applicants will not be allowed to lodge a monetary compensation claim or other action for damages caused by other conditions of their accommodation, and the right to apply to the court will be excluded. Therefore, detainees will be in an awkward situation since no effective legal remedy is granted neither in compensation proceedings under the Hungarian Prison Act nor in a lawsuit concerning the violation of certain rights relating to personality under the Hungarian Code of Civil Procedure or the Civil Code. It is rather doubtful, whether this could 'pass the test' before the ECHR, since the quasi non-recognition of the possibility of accountability is inconceivable under the rule of law.

Keywords: compensation, overcrowding, rights relating to personality, civil lawsuit, new rules

1 Bírósági titkár, Debreceni Törvényszék, e-mail: BodaZoltan@debrecen.birosag.hu

2 Kollégiumvezető, Debreceni Törvényszék Büntető Kollégium, e-mail: nagyantal@debrecenit.birosag.hu 


\section{Bevezetés, „régi” szabályok}

A 2016. évi CX. törvény által beiktatott módosítások révén az alapvető jogokat sértő elhelyezési körülmények miatti kártalanítás, valamint ahhoz kapcsolódóan az emiatti panasz jogintézménye a büntetések, az intézkedések, egyes kényszerintézkedések és a szabálysértési elzárás végrehajtásáról szóló 2013. évi CCXL. törvény (Bv. tv.) 2017. január 1. napjától hatályos módosításával vezették be a magyar jogrendszerbe. Az ezzel kapcsolatos rendelkezéseket föként a 10/A-10/B., 70/A-70/B., 144/B. \$-aiban, valamint a 436 . $\mathbb{\$}(10)-(12)$ bekezdéseiben helyezték el. ${ }^{3}$

A jogalkotó ezzel az Emberi Jogok Európai Bírósága (EJEB) Varga és mások kontra Magyarország ${ }^{4}$ pilot judgement eljárásban ${ }^{5}$ hozott marasztaló ítéletére ${ }^{6}$ kívánt reagálni, megteremtve a fogvatartottak számára az Emberi Jogok Európai Egyezménye (EJEE) 13. cikkének megfelelő hatékony jogorvoslati lehetőséget. Az EJEB ugyanis 2015. március 10-i ítéletében a magyar joggyakorlat megvizsgálását követően arra a megállapításra jutott, hogy a Magyarországon az 1993. évi XXXI. törvénnyel kihirdetett Római Szerződésben biztosított alapvető jogok közül a 3. cikkben meghatározott kegyetlen, embertelen vagy megalázó bánásmód tilalmát sértő fogvatartási körülmények miatt a fogvatartottaknak nem áll rendelkezésére sem hatékony preventív, sem hatékony reparatív jellegű jogorvoslat, ezért fogadta be a közvetlenül hozzá forduló fogvatartottak kérelmeit. Az EJEB ítéletének 47. pontjában kifejtette, a jogorvoslat hatékonysága akkor állapítható meg, ha képes a jogsértést vagy annak folytatását megakadályozni, vagy megfelelő kártérítést tud nyújtani a már megvalósult jogsértésekért. Ehhez mérten sem a fogvatartottak által igénybe vehető panaszt, sem az őket fogva tartó büntetés-végrehajtási intézet elleni, személyiségi jogsértés miatt elöterjesztett nem vagyoni kártérítés iránti pereket ${ }^{7}$ nem tartotta hatékonynak.

Leszögezte, „az Âllam kötelezettsége, hogy a büntetés-végrehajtási rendszerét az anyagi vagy logisztikai nehézségek ellenére is olyan módon szervezze meg, hogy az biztosítsa a fogvatartottak emberi méltósághoz való jogának érvényesülését".

3 Kúria: Emlékeztetö, amely felvételre került az Új Ptk. Jogegységi Csoportok 2018. október 5-ei üléséröl (2018). 6.

4 Varga és mások kontra Magyarország, EJEB, 2015. március 10-i ítélet (ügyszámok: 14097/12, 45135/12, 73712/12, 34001/13, 44055/13 és 64586/13).

5 A pilot judgment eljárásról lásd bővebben Szemesi Sándor: Az emberi jogok európai őrének új fegyvere: a pilot judgement eljárás a strasbourgi bíróság gyakorlatában. Jog-Állam-Politika, 5. (2013), 4. 47-63.

6 Az ítélet ismertetésére lásd Juhász Andrea Erika: Varga és mások kontra Magyarország - az EJEB döntése. Jogászvilág, 2015. április 17; Juhász Andrea Erika: A kínzás, az embertelen, a megalázó bánásmód tilalma a fogvatartottakkal szemben. Doktori értekezés. Szeged, Szegedi Tudományegyetem Állam- és Jogtudományi Doktori Iskola, 2016. 175.

7 Ezzel kapcsolatban meg kell jegyezni, hogy Magyarország példájával szemben az EJEB Lengyelországtól (Latak kontra Lengyelország ügyben) nem kívánta meg egy önálló, formalizált eljárás bevezetését a fogvatartottak kompenzálása érdekében, „megelégedett” a személyiségi jogok megsértésén alapuló polgári jogi per megindításának lehetőségével, hatékonynak minősítette a polgári jogi kárigényt mint jogorvoslati eszközt. (Latak kontra Lengyelország, EJEB, 2010. október 12-i elfogadhatatlansági döntés, ügyszám: 52070/08, 83-85. pont.) 
Emiatt elöírta a Magyar Állam számára olyan „megfelelő” intézkedések bevezetését, amelyekkel az Egyezmény 3. cikkének megsértése esetére alkalmazandó preventív és kártérítési jogorvoslatok rendelkezésre állnak. ${ }^{8}$ Rámutatott arra is, hogy „e cél elérése érdekében az Állam módosíthat már meglévő jogorvoslati lehetőségeket, vagy újakat is bevezethet".

Az EJEB éppen azért döntött a pilot judgement eljárás mellett, mert annak lényege, hogy az Emberi Jogok Európai Egyezményében foglalt jogok védelme érdekében a diszfunkciókat a lehető leggyorsabban és leghatékonyabb módon oldják meg nemzeti szinten. Az eljárást az akkor mintegy 450, az EJEB előtt első vizsgálatra váró Magyarország elleni érdemi kérelem indikálta, amelyekben elsődleges sérelemként a nem megfelelő fogvatartási körülményeket jelölték meg. Mindezek alapján juttatta kifejezésre, hogy nincs meggyőződve arról, hogy a magyar bíróságok által értelmezett és alkalmazott magyar jogszabályok alapján a szerződésen kívüli károkért a panaszosok embertelen vagy megalázó bánásmódra történő hivatkozással kártérítésben részesülhetnek. Így az embertelen vagy megalázó bánásmód következtében megvalósuló személyiségi jogok megsértése miatt benyújtott - akkori terminológia szerint - kártérítés iránti polgári jogi keresetek nem felelnek meg a hatékony jogorvoslati lehetőség feltételeinek, amely alapján észszerü lehetőség van a pernyertességre és a jogorvoslatra. A jogalkotó az EJEB ítéletében írt problémák megoldása érdekében teremtette meg a Bv. tv.-be iktatott kártalanítási eljárást az alapvető jogokat sértő elhelyezési körülményekből eredő sérelmek orvoslására, amelyet a büntetőbíróság hatáskörébe utalt. Célja hatékony, a felróhatóság vizsgálatát nélkülöző reparációs célú jogintézmény megalkotása volt azzal, hogy a cél volt továbbá az is, hogy döntés rövid időn belül, objektív alapon szülessen meg, a határozatok megfelelően indokoltak legyenek, és a döntést késedelem nélkül hajtsák végre. ${ }^{10}$

A fentebb hivatkozott, Varga és mások kontra Magyarország pilot-ítélet nemcsak azzal a következménnyel járt, hogy a jogalkotó lépéseket tett a jogszabályi környezet EJEE 13. cikkének való megfeleltetése érdekében is, hanem - és ennek jelentőségét később külön is kiemelem - a telítettség enyhítése céljából nagyszabású börtönépítési program is kezdődött hazánkban. ${ }^{11}$

Az alapvető jogokat sértő elhelyezési körülmények miatti panasz és kártalanitás tehát a büntetés-végrehajtási jog legújabb jogintézményei, amelyekkel a jogalkotó kettős cél megvalósítását mozdította előre, egyrészt megteremtette a lehetőségét az ilyen

8 Varga és mások kontra Magyarország, EJEB, 2015. március 10-i ítélet 113. pont.

(Az EJEB a Varga-ítélet jogerőre emelkedését követő hat hónapos határidőt szabott Magyarország részére, hogy az Európa Tanács Miniszteri Bizottságával együttműködve állást foglaljon, milyen időtartamon belül tesz intézkedéseket a zsúfoltság csökkentése érdekében, illetve vezeti be a megfelelő jogorvoslati lehetőségeket.)

9 Kúria (2018): i. m. 6-7.

10 Kúria (2018): i. m. 7.

11 Bagossy Mária: Kártalanítás az alapvető jogokat sértő elhelyezési körülmények miatt. In Mailáth György Tudományos Pályázat 2018. Díjazott dolgozatok. Budapest, Országos Bírósági Hivatal, 2018. 260. 
jellegủ sérelmekből adódó károk viszonylag egyszerű eljárás keretében való enyhítésének és ellentételezésének, másrészt a magyarországi jövedelmi viszonyokhoz igazodó kártalanítási összeget határozott meg. ${ }^{12}$ Noha a közvélemény kevéssé támogatja a hazai börtönkörülmények ily módon történő kompenzációját, ${ }^{13}$ a panasz- és kártalanítási eljárás már egy szempontból mindenképpen sikeresnek mondható: az EJEB a Domján kontra Magyarország ügyben 2017. november 14. napján kelt határozatá$\mathrm{val}^{14}$ azt egyezménykonformnak minősítette.

A szabályozás lényege szerint (Bv. tv. 2020. december 31. napjáig hatályban volt 10/A. \$) kártalanítás jár az elítéltnek a fogvatartása során a jogszabályban előírt élettér biztosításának hiánya és az ehhez esetlegesen kapcsolódó más, a kínzás, kegyetlen, embertelen vagy megalázó bánásmód tilalmába ütköző elhelyezési körülmény, különösen az illemhely elkülönítésének a hiánya, a nem megfelelő szellőztetés, világítás, fütés vagy rovarirtás (a továbbiakban együtt: alapvető jogokat sértő elhelyezési körülmények) által előidézett sérelem miatt. A kártalanítás minden egyes, az alapvető jogokat sértő elhelyezési körülmények között eltöltött nap után jár, és annak megfizetésére az állam köteles.

Az előző felsorolás a Kúria joggyakorlat-elemző csoportjának megállapítása szerint ugyanakkor nem taxatív, a jogalkotó a legjellemzőbb esetköröket nevesítette - a kártalanítás nem felróhatósági alapú jogkövetkezményének lehetőségét a jogalkotó tehát leginkább kizárólag ezekhez a „tényállásokhoz” kapcsolta -, amelyeket az EJEB elötti és a magyarországi kártérítési perek tapasztalataira alapított, hozzákapcsolva a szabadságvesztés, az elzárás, az előzetes letartóztatás és a rendbírság helyébe lépő elzárás végrehajtásának részletes szabályairól 16/2014. (XII. 19.) IM rendelet szabályozott esetköreihez. A gyakorlati tapasztalatok azt mutatják, hogy a kártalanítási eljárásban bírálják el a megfelelő légtér, mozgástér hiánya, az önálló szellőzésű WC hiánya, a tisztálkodáshoz szükséges folyóvíz, fürdő hiánya, az illemhely elkülönítésének hiánya, a nem megfelelő szellőztetés, világítás, fütés és rovarirtás hiánya miatti igényeket. ${ }^{15}$ A kártalanítási eljárással rendezni célzott sérelem tehát kizárólag az elhelyezési körülményekhez kapcsolódhat, más, például az élelmezés minőségével, a fogvatartottakkal való bánásmóddal, az egészségügyi ellátással kapcsolatos sérelmek nem alapozhatnak meg kártalanítási igényt. ${ }^{16}$

Meg kell jegyezni ugyanakkor, hogy éppen a fenti értelmezéssel ellentétes az a kialakult büntetés-végrehajtási gyakorlat, amely a fenti felsorolást taxatívnak értelmezi, és az azokon kívül megjelölt körülményekre történő hivatkozás vizsgálatát teljes mértékig elveti.

12 Kúria (2018): i. m. 8.

13 Bagossy (2018): i. m. 284-285.

14 Domján kontra Magyarország, EJEB, 2017. november 14-i határozat (ügyszám: 5433/17); Bagossy (2018): i. m. 252.

15 Mindezek biztosításának módját külön jogszabályok rendezik, a 16/2014. (XII. 19.) IM rendelet mellett például a Büntetés-végrehajtás Országos Parancsnokának szakutasításai is.

Kúria (2018): i. m. 8-9. 
A 2020. december 31. napjáig hatályban volt Bv. tv. 10/A. $\mathbb{\$}(2)$ bekezdése szerint a fentebb meghatározott jogcímen (kártalanítás) további kártérítésnek vagy sérelemdíjnak helye nincs, de az elítélt jogosult az ezt meghaladó igényét polgári bíróság előtt érvényesíteni.

A módosítás egyik markáns pontja volt a Bv. tv. 10/A. $\mathbb{\$}(6)$ bekezdése, amely szerint a kártalanítás iránti igény benyújtásának feltétele az is, hogy az elítélt vagy - a kényszergyógykezelt, illetve az ideiglenesen kényszergyógykezelt kivételével az egyéb jogcímen fogva tartott az alapvető jogokat sértő elhelyezési körülmények miatt a 144/B. \$-ban meghatározott panaszt előterjessze a végrehajtásért felelős szerv vezetőjéhez. Ez a feltétel akkor alkalmazandó, ha az alapvető jogokat sértő elhelyezési körülmények között töltött napok száma a 30-at meghaladja. Ha az alapvető jogokat sértő elhelyezési körülmény hosszabb időn át fennáll, három hónapon belül újabb panaszt előterjeszteni nem kell. Nem róható az elítélt vagy az egyéb jogcímen fogva tartott terhére, ha rajta kívül álló okból nem tudta a panaszjogát érvényesíteni.

Ezen feltétel teljesülésének hiányához pedig a kérelem érdemi vizsgálat nélküli elutasításának következményét füzte a $\mathrm{Bv}$. tv. 70/A. $\mathbb{S}(5)$ bekezdés $c$ ) pontja, amely kimondta, hogy a büntetés-végrehajtási bíró a kérelmet érdemi vizsgálat nélkül az iratok alapján elutasítja, ha az elítélt a 144/B. \$-ban meghatározott panaszt nem terjesztette elő. Ez illeszkedett a Bv. tv. 21. \$-ában előírtakhoz, miszerint a büntetés-végrehajtási jogviszony keretében az elsődleges jogorvoslati forma a panasz, amelyet a végrehajtásért felelős szerv intézkedése vagy döntése ellen, illetve annak elmulasztása miatt a végrehajtásért felelős szerv vezetőjéhez lehet benyújtani. ${ }^{17}$

\section{Az alapvető jogokat sértő elhelyezési körülmények miatti kártalanítás új szabályai ${ }^{18}$}

2020. december 18. napján kihirdették a börtönzsúfoltság miatti kártalanítási eljárással összefüggő visszaélések megszüntetése érdekében szükséges egyes törvények módosításáról szóló 2020. évi CL. törvényt (Mód. tv.).

17 Ez illeszkedett a Bv. tv. 21. \$-ában elöírtakhoz, miszerint a büntetés-végrehajtási jogviszony keretében az elsődleges jogorvoslati forma a panasz, amelyet a végrehajtásért felelős szerv intézkedése vagy döntése ellen, illetve annak elmulasztása miatt a végrehajtásért felelős szerv vezetőjéhez lehet benyújtani. Boda Zoltán: Az alapvető jogokat sértő elhelyezési körülmények miatt indított kártalanítás aktuális jogértelmezési kérdései. Acta Humana, 8. (2020), 1. 20. hivatkozza: Fővárosi Törvényszék 2018. december 15. napján kelt összefoglaló anyagának 6. oldala.

18 A Bv. tv. szerinti kártalanítás új szabályairól lásd még például Nagy Zsuzsanna - Boda Zoltán: Az alapvető jogokat sértő elhelyezési körülmények miatti kártalanítás új szabályai, visszatekintés a panasz jogintézményére. Büntetőjogi Szemle, (2020), 2. 99-112; Boda Zoltán: Az alapvető jogokat sértő elhelyezési körülmények miatti kártalanítási eljárás és a személyiségi jogsértés miatt indult polgári per konkurálása. Acta Universitatis Szegediensis FORVM: Publicationes Doctorandorum Juridicorum, 11. (2021). 5-22. 
A jogalkotó végső előterjesztői indokolásának általános részében találhatjuk meg a változtatások szükségességének okát:

„[...] [A] jogalkotó eredeti szándéka egy hatékony és jól müködő intézmény létrehozására irányult, a rendszer müködésének tapasztalatai azonban azt mutatták, hogy a kártalanítási rendszer ebben a formában nem megfelelő. A szabályozási ambivalencia akkor vált jogalkotói lépést is igénylő mértékűvé, amikor egyértelművé vált, hogy akkor, amikor az elítéltek az alapvető jogokat sértő elhelyezési körülmények miatt gyakran jelentős összegü kártalanításban részesülnek, a szabadságvesztés büntetés kiszabására vezető büncselekmény áldozatai és hozzátartozóik sérelmei ebböl alacsony mértékben nyernek reparálást. Emellett nyilvánvalóvá váltak a börtönviszonyokkal kapcsolatos kártalanítás miatt indított perek körüli visszaélések, amelyek súlyosan sértették a társadalom igazságérzetét. Széles körben ismertté vált, hogy egyes esetekben a közvéleményt mélyen megrázó bűncselekmények miatt elítélt személyek is milliós nagyságrendủ kártérítésekhez juthattak, miközben a bűncselekmények áldozatai és hozzátartozói esetében nem volt kellően hatékony az igényérvényesítés lehetősége. [...]

Szükségessé vált ezért egy olyan új szabályozás kidolgozása, amely amellett, hogy megfelelö lehetöséget ad az áldozati igények érvényesitésére, biztositja azt is, hogy a kártalanitásként kapott összeg, ha az elitéltnek egyéb kielégitésre köteles kötelezettségei vannak, a megtérülés alapjául szolgálhasson az önkéntes teljesités elmaradása esetén. Ennek megfelelően a törvényjavaslat célja egyrészt a kártalanításból közvetlenül levonható követelések bővítése a terhelttel szemben fennálló és végrehajtás alatt álló valamennyi magánjogi jogviszonyból eredő tartozás esetében, különös tekintettel a terhelt korábban elkövetett büncselekményével okozott sértetti igényekre. Másrészt cél az is, hogy a kártalanításból közvetlenül nem levonható, de a végrehajtás számára hozzáférhetővé tehető követelések bevonhatóvá váljanak a kártalanítási eljárásba, így különösen a büntetőeljárással összefüggésben megfizetendő tartozások behajtásának (bünügyi költség, vagyonelkobzás stb.), továbbá bármilyen, az állammal szemben fennálló köztartozás (pl. adótartozás) behajtásának lehetővé tétele. Végül a törvényjavaslat hatékonyabbá kívánja tenni a kártalanítási eljárást is, sok egyéb módosítás mellett ezért bevezeti a kártalanítási eljárás egyszerűsítése és gyorsítása érdekében a kérelmek egyszerűsített elbírálását a mérlegelést nem igénylő esetekben.”

A Mód. tv. egyik leglényegibb új szabálya, hogy egyszerüsíti a kártalanítási folyamatot azzal, hogy megszünteti a kérelem benyújtásának előfeltételeként az elhelyezési körülmények miatt benyújtott panasz kötelezö elöterjesztésének az elöírását. Ennek oka, hogy a jogalkotónak is feltüntek a jogintézménnyel kapcsolatos értelmezési (jogalkalmazási) bonyodalmak. A börtönzsúfoltság miatti kártalanítási eljárással összefüggő 
visszaélések megszüntetése érdekében szükséges egyes törvények módosításáról szóló T/13954. számú törvényjavaslat szerint:

„[A] kártalanítás hatályos szabályainak felülvizsgálata annak megállapítására jutott, hogy ez a jogintézmény valójában csak feleslegesen terheli a büntetés-végrehajtási szervezetet, hiszen nem eredményezi a kártalanítási felelősség alóli mentesülést, ugyanakkor számos esetben jogértelmezési problémát generál."19

Kétségtelen, hogy a Bv. tv. 75/I. \$-a kapcsán a javaslat indokolása ${ }^{20}$ azt is rögzíti, hogy a korábban hatályos rendszerben a bv. intézet kártalanítási eljárásban betöltött szerepét a panasz intézménye jelentősen meghatározza. Bevezetését az a törekvés indokolta, hogy olyan mechanizmust is meg kívánt teremteni a jogalkotó, amely preventív jogorvoslatot is jelent a kompenzáció nyújtására alkalmas vagyoni kártalanítás mellett, vagyis a bv. intézetnek olyan kötelezettséget is kellett elöírni, amely alapján biztosítania kell, hogy a sérelmes elhelyezési körülményt a bv. szervezeten belül meg tudja szüntetni.

Mindezen okokból magát az intézményt a jelenleg hatályos szabályozás nem tartja meg, ugyanakkor az intézményt életre hívó követelmények, amelyek azt hivatottak biztosítani, hogy a bv. intézet az elhelyezési körülményekkel kapcsolatos sérelmeket mihamarabb orvosolja, intézkedési kötelezettség formájában fennmaradnak. ${ }^{21}$

A módosítás eredményeként 2021. január 1. napi hatálybalépéssel egy helyre, önálló, külön fejezetbe (III/A. Fejezet) kerültek a kártalanítás intézményére és eljárási rendjére vonatkozó szabályok, amelynek célja és tartalma a korábbi szabályozáshoz képest azonban nem változott. A kártalanítás az elítéltnek vagy az egyéb jogcímen fogva tartottnak a fogvatartása során a jogszabályban előírt élettér biztosításának hiánya és az ehhez esetlegesen kapcsolódó más, a kínzás, kegyetlen, embertelen vagy megalázó bánásmód tilalmába ütköző elhelyezési körülmény által előidézett sérelem miatt járhat továbbra is.

A kérelem benyújtására vonatkozó időbeli, formai és tartalmi követelményeket (75/D. \$) annyiban módosították, hogy a módosító törvény meghatározott időtartamonként teszi csak lehetővé a kártalanítási igény érvényesítését. ${ }^{22}$

Újabb lényegi változásnak tekinthető, hogy a módosító törvény bevezeti az egyszerüsitett kártalanitási eljárást, amelynek intézményes kereteit és lefolytatását - taxatíve meghatározva ${ }^{23}$ azokat a feltételeket, amelyek fennállása esetén a kártalanítási kérelem egyszerűsített elbírálásának van helye - a bv. szervezet feladatává teszi azzal a céllal, hogy az új eljárási forma révén az érintett gyorsabban juthasson hozzá

19 A börtönzsúfoltság miatti kártalanítási eljárással összefüggő visszaélések megszüntetése érdekében szükséges egyes törvények módosításáról szóló T/13954. számú törvényjavaslat, 2020. 44.

20 T/13954. számú törvényjavaslat, 2020. 47.

21 Bv. tv. 75/I. \$.

22 Bv. tv. 75/D. $\$$ (2) és (3) bekezdés.

23 Bv. tv. 75/G. $\mathbb{}$. 
a kártalanításhoz, ugyanakkor - elkerülendő, hogy a bv. intézetre mérlegelést igénylő többletfeladat háruljon - jelenleg a Bv. tv.-ben meghatározott kártalanítási összeg minimuma (1200 Ft/nap) járna ilyen esetben, ellentétben az alapvető jogokat sértő elhelyezési körülmények teljes vizsgálatát elvégző bírói elbírálással. Az újonnan hatályba lépő szabályok kártalanítási kérelemről való „döntési fórumot” megosztották a bv. intézet és a bv. bíró között, amely megkülönböztetésnek az az alapja, hogy a kártalanítási kérelemről a bv. intézet által összeállított anyag alapján hozható-e érdemi döntés, vagy sem. Amennyiben a sértetti igények felderítését is el kell végezni, akkor mindenképpen bv. bírói eljárást kell lefolytatni (bv. intézet nem végzi el a sértett megkeresését az esetlegesen fennálló polgári jogi igény érvényesítésével kapcsolatban).

A bv. szervezet általi egyszerüsített elbírálásnak nem akadálya, ha az élettéren kívül a kérelmező más körülményt is kifogásol. Azonban a bv. szervezet által lefolytatott kártalanítási eljárás esetében az is lényeges szempont, hogy az érintett minél gyorsabb és egyszerủbb eljárásban jusson hozzá a kártalanítás összegéhez, ezért a kérelem elbírálásakor az élettéren kívül más körülményt nem kell vizsgálni. ${ }^{24}$

Az egyszerűsített eljárásban, a bv. szervezet által hozott határozattal szemben nincs helye jogorvoslatnak, azonban az elítélt vagy a védő a határozat kézbesítését követő nyolc napon belül előterjesztett ilyen irányú kérelmére a bv. intézet az elbíráláshoz szükséges iratokkal együtt köteles a kérelmet a bv. bíróhoz továbbítani, egyúttal külön intézkedés nélkül hatályát veszti az ügyben a bv. intézetnek az egyszerűsített elbírálásról szóló határozata. ${ }^{25}$

Az egyszerűsített elbírálás mellett a módosító törvény a bv. szervezethez utal egy másik lényegi „hatáskört”, a kártalanítási kérelem visszautasitását. ${ }^{26}$ Mindezt úgy vezette be a jogalkotó, hogy a kérelem visszautasítása esetén a bv. intézetnek tájékoztatást kell adnia a visszautasítás pontos okáról, illetve a visszautasítási ok elhárításához szükséges hiányosságok pótlásának a lehetőségéről, ${ }^{27}$ és az elítélt/egyéb jogcímen fogvatartott vagy a védő a visszautasítást követően nyolc napon belül előterjesztett ilyen irányú kérelmére a bv. intézet az elbíráláshoz szükséges iratokkal együtt köteles a kérelmet a bv. bíróhoz továbbítani, egyúttal külön intézkedés nélkül hatályát veszti az ügyben a bv. intézetnek a visszautasításról szóló határozata. ${ }^{28}$

Azonban itt kérdésként felmerül, hogy ha korábban a panasz elbírálása is komoly terhet jelentett a végrehajtásért felelős szerv részére, akkor mennyiben lesz könnyebb dolga a büntetés-végrehajtási intézeteknek az egyszerüsített kártalanítási eljárás, a visszautasítás intézésével. Aggályként tudnám megfogalmazni például azt, hogy ugyanúgy vizsgálniuk kell a kérelmek elintézésekor a Bv. tv. 75/B. \$ (5) bekezdésének II. fordulatában foglaltakat annak fényében, hogy ha legalább 30 napra megszakadt a jogsérelem, ilyen esetben hogyan kell figyelembe venni a hat hónapos igényérvénye-

24 Bv. tv. 75/G. $\$(1)-(2)$ bekezdés.

25 Bv. tv. 75/G. \$ (6)-(7) bekezdés.

26 Bv. tv. 75/F. $\$$.

27 Bv. tv. 75/F. $\$(2)$ bekezdés.

28 Bv. tv. 75/F. $\$(3)-(4)$ bekezdés. 
sítési határidőt, ami akár ahhoz vezethet, hogy a kérelmet egy részében vissza kell utasítani elkésettség okán. Figyelembe kell venni azt is, hogy a hat hónapos határidő nem anyagi jogi, hanem eljárásjogi határidő, így a postára adás napja számít, és nem a bv. intézet érkeztetése. A határidő elmulasztása miatt ugyanakkor igazolási kérelemnek is lehet helye, amelyet így szintén a bv. intézetnek kellene elbírálni. Visszatérve a hat hónapos határidőre, még a bv. bírói gyakorlatban sem alakult ki egységes álláspont annak vonatkozásában, hogy ha 30 napot meghaladó időtartamban biztosítva volt a kérelmező részére a jogszabályban meghatározott élettér, akkor ilyen esetben a hat hónapos igényérvényesítési határidő a megszunnés első napjával vagy a 31. naptól kezdődik. Az ilyen és ehhez hasonló jogértelmezési kérdések bv. szervezethez történő telepítése komoly kihívás elé állíthatja a bv. szerveket.

Visszatérve az egyszerüsitett elbiráláshoz, a Bv. tv. a 75/G. $\mathbb{S}$ (2) bekezdés alapján tehát az élettér hiányához kapcsolódó más alapvető jogot sértő elhelyezési körülményt (a „különösen” kitétellel kiemelt sérelmes elhelyezési körülmények - amelyekre történő hivatkozás a leggyakrabban előfordul - a zárkák rovarfertőzöttsége, az illemhely nem megfelelő szellőztetése és leválasztásának hiánya, a zárkákban a meleg víz hiánya, míg a szintenként kialakított zuhanyzókban a hideg és a meleg víz hiánya, a zárkákban a természetes és a mesterséges fény hiánya, a zárkák ablakain a kilátásgátlók felhelyezése, a zárkákban és a zuhanyzókban a téli hónapokban a nem megfelelő hőmérséklet) a bv. intézet nem fogja vizsgálni az egyszerüsitett eljárás során, holott a gyakorlat azt mutatja, hogy elenyésző az olyan kérelmek száma, amelyek kizárólag csak a nem megfelelő mértékủ élettér hiányát nevesítik.

Fentiek alapján előfordulhat, hogy az egyszerűsített kártalanítási eljárás hasonlóan súlytalan jogintézménnyé válhat, mint a panasz jogintézménye, csak más indokok alapján.

Azokban az esetekben, amikor a fogvatartott által sérelmesnek tartott elhelyezési körülmények a rendelkezésre álló adatok alapján megállapíthatóan nem felelnek meg a jogszabályi előírásoknak, az általam helyesnek tartott gyakorlat szerint a bv. bíró/ titkár minden esetben súlyozta az egyéb elhelyezési körülményeket a döntése meghozatalakor, egyéb esetekben kimondta, hogy alaptalan az erre vonatkozó hivatkozás, amely megállapítását indokolta is.

Ugyanakkor a differenciálásnak is van több gyakorlata a különböző bv. csoportoknál:

- bv. intézetenként eltérő, de egy az adott bv. intézetben valamennyi napra ugyanakkora napi tételösszeg meghatározása;

- túlzsúfoltság esetén $1200 \mathrm{Ft}$ napi összeg, és ha van más sérelem is, akkor nő az összeg;

- túlzsúfoltság mértékétől is függ a napi tétel összege (1200/1400/1500 Ft), és ha van más sérelem is, akkor még tovább nőhet az összeg: például $4,00 \mathrm{~m}^{2}$ egy főre jutó élettér helyett $0,00-0,99 \mathrm{~m}^{2}$ élettéren töltött napokra $1500 \mathrm{Ft}, 1,00-1,99 \mathrm{~m}^{2}$ élettéren töltött napokra $1400 \mathrm{Ft}, 2,00-2,99 \mathrm{~m}^{2}$ élettéren töltött napokra $1300 \mathrm{Ft}$, 3,00-3,99 $\mathrm{m}^{2}$ élettéren töltött napokra $1200 \mathrm{Ft}$. 
Ezen differenciáló gyakorlatot egyértelmủen helytelennek ítélem meg, hiszen az EJEB is kifejtette, hogy a fogvatartási körülmények értékelése során a körülmények által kifejtett kumulatív hatást szükséges vizsgálni. ${ }^{29}$

Az eddigi bv. bírói gyakorlat tapasztalatai alapján szintén fajsúlyos kérdés, hogy a kártalanítás iránti kérelmek többségükben azt mutatták, hogy azok az érdemi elbírálást akadályozó mértékben hiányosak, gyakorta a sérelmek részletezése nélkül, pusztán csak az eljárás lefolytatását kéri az elítélt. A Mód. tv. ezért a probléma megoldására kifejezetten rendelkezik a hiánypótlás lehetőségéről. ${ }^{30} \mathrm{~A}$ kérelemhez kötöttséghez kapcsolódóan a hiánypótlásra előírt határidő leteltét követően döntéshozatali kötelezettséget ír elő a bíró számára, vagyis a bv. bíró ilyen esetben a döntését a rendelkezésre álló adatok alapján fogja meghozni. ${ }^{31}$ Ezzel egyidejüleg a Mód. tv. a kérelem érdemi vizsgálat nélküli elutasitására vezető esetköröket - a panasz vizsgálatának kötelezettsége nélkül - átveszi, egyúttal ki is egészíti azokat: ilyen a kártalanítás iránti kérelem benyújtására vonatkozó időbeli vagy formai feltételek vizsgálata, továbbá, ha a hiánypótlási felhívás eredményeként sem lehet a kérelemről érdemben dönteni - a gyakorlatban például számos esetben előfordult eddig, hogy a szabadult kérelmező nem adott meg kifizetési számlaszámot, amelynek hiányában nem kerülhet sor végrehajtható határozat meghozatalára. Ugyanilyen elutasítási okként vezették be azt az esetkört, ha azonos sérelmezett időszakra vonatkozóan a kérelmező a Bv. tv. alapján már kapott kártalanítást. ${ }^{32}$

Ugyanakkor a számlaszámmal összefüggésben meg kell jegyezni, hogy az álláspontom szerint továbbra is „fejtörésre” ad okot. Amennyiben a kérelmező felhívás ellenére nem adott meg a szabadlábra helyezését követően olyan fizetési számlaszámot, amelynek számlatulajdonosa és a számla feletti kizárólagos rendelkezési jogosultja maga az elítélt, ${ }^{33}$ két eltérő gyakorlat alakult ki a törvényszékek bv. csoportjainál. Az egyik szerint amennyiben a törvényszék által megadott határidőben a megkeresésre nem válaszolt a kérelmező (nem adott meg számlaszámot), az érdemi határozathozatal mellőzésével az iratokat irattárba helyezte - és erre a lehetséges következményre már a megkeresésben felhívta a kérelmező figyelmét. A másik gyakorlat szerint abban az esetben, ha a kérelmező nem adott meg ilyen kifizetési számlaszámot, az az eljárás felfüggesztéséhez vezetett. Ezen utóbbit azonban nem tartom követendőnek a jövő-

29 Dougoz kontra Görögország, EJEB, 2001. március 6-i ítélet, ügyszám: 40907/98, 46. pont.

30 Arra a kérdésre, hogy hiánypótlás esetén melyik bv. intézet lesz az adatszolgáltatásra köteles, álláspontom szerint a 16/2014. (XII. 19.) IM rendelet 10/B. \$ (2) bekezdését kell felhívni, amely szerint ha a kártalanítási kérelemben megjelölt fogvatartási időszak több bv. intézetet is érint, a kérelem elbírálásához szükséges adatokat a kérelemről döntésre jogosult bv. intézet gyüjti össze. A kérelemről döntésre jogosult bv. intézet kapcsán pedig a Bv. tv. 75/D. $\$(4)$ bekezdésében foglaltak az irányadók, amely szerint a kártalanítási kérelmet a jogszabályban a kérelem benyújtására rendszeresített nyomtatványon, a fogvatartás helye szerinti bv. intézetnél, ha pedig az elítélt már szabadult, annál a bv. intézetnél kell benyújtani, ahonnan a szabadítás történt.

31 Bv. tv. 75/K. $\$$ (3) bekezdés.

32 Bv. tv. 75/L. $\$$.

33 Jelenleg Bv. tv. 75/S. $\$(1)$ bekezdés $a$ ) pont $a b$ ) alpont. 
ben sem, hiszen ilyen felfüggesztési okot sem maga a Bv. tv., sem pedig a háttérjogszabály Be. nem szabályoz, így e döntésnek hiányzik a jogszabályi alapja.

A további fejtörésnek az lehet az oka, hogy most már a Bv. tv. 75/F. $\mathbb{S}(1)$ bekezdés e) pontja szerint a bv. intézet a kérelmet visszautasítja, ha a kérelem nem tartalmazza a jogszabályban meghatározott adatokat, és ezért érdemi elbírálásra alkalmatlan; a Bv. tv. 75/L. $\$ e$ ) pontja pedig - hasonlóan az előző rendelkezéshez - kimondja, hogy a büntetés-végrehajtási bíró a kérelmet annak a bírósághoz érkezését követően 30 napon belül érdemi vizsgálat nélkül az iratok alapján elutasítja, ha a kérelem a 75/K. $\mathbb{S}$ (3) bekezdése szerinti hiánypótlás ellenére érdemi elbírálásra alkalmatlan.

Fel kell tenni tehát azt a kérdést, hogy vajon, ha a kérelmező nem ad meg kifizetési számlaszámot, akkor az érdemben elbírálhatatlanná teszi-e a kérelmet. Az egyik általam ismert álláspont szerint ettől még a kérelem érdemben elbírálható, „csupán” végrehajtatlan lesz a határozat, amely problémát a kifizető Igazságügyi Minisztériumnak kell feloldania. Ettől eltérő értelmezés szerint - amelyet én is helyesnek ítélek - a bíróságnak mindenképpen végrehajtható határozatot kell hoznia, hiszen ebben áll a bírósági jogalkalmazás, igazságszolgáltatás lényege, mondhatni a bíróságok „küldetése”. A bíróságok szervezetéről és igazgatásáról szóló 2011. évi CLXI. törvény (Bszi.) 2. \$ (1) bekezdése szerint is: „[A] bíróságok a vitássá tett vagy megsértett jogról, [...] - törvényben szabályozott eljárás során - véglegesen döntenek." A (2) bekezdés szerint pedig: „, [A] bíróságok a jogalkalmazási tevékenységük során biztosítják a jogszabályok érvényesülését." Erre tekintettel úgy gondolom, hogy a végrehajthatatlan határozatok meghozatala éppen a jogszabály érvényesülését zárja ki.

Ezen álláspontomat támasztja alá a fogva tartott személy esetében a büntetőeljárás lefolytatása, továbbá a büntetöügyekben hozott határozatok végrehajtása során a bíróságokra és egyéb szervekre háruló feladatokról szóló 9/2018. (VI. 11.) IM rendelet 124 . $\$(1)$ bekezdés $c$ ) pontja is, amely szerint a kártalanítás megállapításáról szóló határozat rendelkező részének tartalmaznia kell a kártalanítás kifizetéséhez szükséges

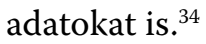

A Mód. tv. rendezi azokat a „függő" ügyeket is, amelyek végleges befejezését eddig a kérelmező ismeretlen helyre távozása akasztott meg. Ha a kérelmező a kérelem benyújtását követően ismeretlen helyre távozott, és a bv. bíró az eljárást felfüggeszti, öt év elteltével az eljárás megszünik. ${ }^{35}$

Uj, lényegi változásként emelem ki továbbá a kártalanítás kapcsán eljáró bv. bírói illetékességi szabályok azon módosulását, amely szerint - amelyet valószínűleg olyan célszerüségi szempontok indokoltak, mint például hogy az egyes fogvatartási

34 Meg kell jegyezni ugyanakkor, hogy a Bv. tv. 75/Q. \$-a reagált arra a korábban gyakran előforduló helyzetre, amikor a végrehajtás jelentősen elnehezült, ha a bírói döntés meghozatala és a kifizetés közötti időszakban az elítélt szabadulására került sor, hiszen ekkor a bv. intézetben az elítélt számára vezetett letéti számla megszűnésével a kérelem benyújtásakor megjelölt teljesítési hely megváltozott. Ennek elkerülése érdekében a hivatkozott jogszabályhely beiktatta a kifizetést megelőzően a szabadulás időpontjára vonatkozó adatkérést, és részletesen szabályozza az annak eredménye alapján folytatandó eljárást. 
időszakokon belül az alapvető jogokat sértő körülmények között töltött napok számának meghatározásával járó adminisztratív terhek teszik szükségessé - a bv. bíró illetékessége rögzül, így a kérelmező átszállítása esetén már nem kerülhet sor áttételre ${ }^{36}$ az új fogvatartási hely szerint illetékes bv. bíróhoz. ${ }^{37}$

Ennek a szabálynak a megfogalmazása ugyanakkor semmiképp nem volt „szerencsés", hiszen a jogalkotó a $75 / J . \$(1)$ bekezdésében két, egymással ellentétbe kerülő illetékességi szabályt rögzített, és felmerülhet kérdésként, hogy a szabadulás esetére, utóbb írt szabály megelőzi-e a bekezdésben elsőként írt rendelkezést. Tehát: ha a kérelmező szabadult, akkor az utóbb megfogalmazott illetékességi szabály alapján van-e helye a kérelem áttételének a szabadítást végző bv. intézet székhelye szerinti bv. bíróhoz annak ellenére, hogy azt nem ott (a bv. bíró székhelyéhez igazodó bv. intézetben) nyújtották be korábban. A Mód. tv. végső előterjesztői indokolása azonban azt rögzíti, hogy:

„Azt indokolják, hogy a büntetés-végrehajtási bíró illetékessége e bv. intézetre tekintettel rögzüljön, és az az elítélt átszállítása esetén ne kerüljön sor áttételre az új fogvatartási hely szerint illetékes bv. bíróhoz. A törvényjavaslat az illetékesség megváltozásának a kizárásával az általános illetékességi szabályoktól való eltérést teremti meg, melynek eredményeként a jövőben az elítélt, illetve az egyéb jogcímen fogvatartott átszállítása esetén az eljáró büntetés-végrehajtási bírónak nem kell az iratokat illetékességből áttennie, és elkerülhető egy áttétellel együtt járó újbóli irattanulmányozás. A hatályos szabályozáshoz hasonlóan a már szabadult elítélt esetében az illetékességi szabály, hogy a kártalanítási eljárást a szabadítást végző bv. intézet székhelye szerint illetékes büntetés-végrehajtási bíró folytatja le, ugyanakkor megmarad az a kivételes illetékességi szabály is, amely alapján az elítélt vagy a védő ilyen irányú kérelmére az elítélt lakcíme vagy tényleges tartózkodási helye szerint illetékes büntetés-végrehajtási bíró jár el. A törvényjavaslat ugyanakkor rögzíti, hogy ilyen indítványt kizárólag a kártalanítás iránti kérelemben lehet előterjeszteni, az eljárás későbbi szakaszában már nem."

Jómagam azt az értelmezést támogatnám, amely szerint, ha a kérelmező fogvatartása során terjeszti elő a kérelmét az éppen őt fogva tartó bv. intézetnél, akkor a jogalkotó kimondott szándéka szerint ennél a bv. intézetnél, illetve az „ahhoz tartozó” bv. bírónál rögzüljön az illetékesség, még annak ellenére is, ha esetleg időközben a kérelmezőt átszállítják másik bv. intézetbe, hogy onnan szabaduljon. Abban az esetben kellene alkalmazni az előzőkből kifolyólag a szabaduláshoz kötődő illetékességi sza-

36 Erre a 2020. december 31. napjáig volt gyakorlat szerint mindig a Kúria Bkk.I.926/2017/5. számú végzésében foglaltak alapján került sor, amely szerint annak, hogy a kérelmet melyik büntetésvégrehajtási intézetnek nyújtotta be a terhelt, nincs jelentősége; az illetékességet az alapozza meg, hogy a kártalanítási igény elbírálásakor melyik intézet hajtja végre a büntetést.

37 A szabadítást végző bv. intézet székhelye szerint illetékes bv. bíró változatlan szabályként megmaradt. E mellett pedig az a kivételes illetékességi szabály továbbra is alkalmazandó, amely alapján a kérelmező vagy a védő ilyen irányú kérelmére az elítélt/egyéb jogcímen fogvatartott lakcíme vagy tényleges tartózkodási helye szerint illetékes bv. bíró járhat el. Bv. tv. 75/J. \$. 
bályt, amikor a kérelmező a kérelmét értelemszerűen a szabadulás után terjeszti elő (a szabadítást végző bv. intézetnél). Úgy vélem, hogy ez az értelmezés vezethet a jogalkotó azon szándékának megvalósulásához, hogy a kérelmek indokolatlan áttételére ne kerüljön sor, ezzel az eljárást ok nélkül elhúzva.

Az a szabály pedig, amely szerint az arra vonatkozó indítványt, hogy az elítélt lakcíme vagy tényleges tartózkodási helye szerint illetékes büntetés-végrehajtási bíró járjon el, kizárólag a kérelemben lehet előterjeszteni, kifejezetten örvendetes új rendelkezés, hiszen ez a korábbi gyakorlatban komoly terhet jelentett a bv. csoportoknak és a kérelmezőknek is „visszaélésekre adott okot”.

Szükséges foglalkozni a Mód. tv. átmeneti rendelkezéseivel is, különösen azokkal, amelyek a folyamatban lévő eljárásokkal vannak összefüggésben. A Bv. tv. 436/A. \$ (1) bekezdése szerint e törvénynek a Mód. tv. 17. \$-ával megállapított III/A. fejezetét - a (2) bekezdésben meghatározott kivétellel - a Mód. tv. 17. \$-ának a hatálybalépésekor (2021. január 1.) folyamatban lévő eljárásokban is alkalmazni kell. A (2) bekezdés szerint e törvénynek a Mód. tv. 17. \$-ával megállapított
a) 75/D. $\mathbb{\$}(2)-(4)$ bekezdését, ${ }^{38}$
b) $75 / \mathrm{F} . \mathbb{S}(1)$ bekezdés $b$ ) és $d$ ) pontját, ${ }^{39}$
c) $75 / \mathrm{K} . \mathbb{S}(2)$ bekezdését $^{40}$ és
d) $75 /$ L. $\$ b$ ) és $d$ ) pontját ${ }^{41}$

a Mód. tv. 17. \$-ának a hatálybalépését követően benyújtott kérelmek esetén kell alkalmazni.

Ezzel kapcsolatban tehát az a kérdés vetődött fel, hogy mivel föszabály szerint a 2021. január 1. napján hatályba lépett változásokat a folyamatban lévő ügyekben is alkalmazni kell, erre tekintettel van-e arra lehetősége a bíróságnak, hogy azokat a folyamatban lévő ügyeket, amelyekben nincs sértett, egyszerüsített elbírálás végett visszaküldje a büntetés-végrehajtási intézetnek?

38 75/D. \$ (2) bek.: Első alkalommal a kártalanítási kérelem akkor nyújtható be, ha az alapvető jogokat sértő elhelyezési körülmények legalább két hónapig fennálltak, kivéve, ha a) a fogvatartott ennél hamarabb szabadul vagy b) az alapvető jogokat sértő elhelyezési körülmények ennél rövidebb idő után megszűntek.

(3) A kártalanítási kérelem benyújtásától számított hat hónapon belül újabb kérelem nem terjeszthető elő, kivéve, ha a) a fogvatartott ennél hamarabb szabadult vagy b) az alapvető jogokat sértő elhelyezési körülmények ezalatt az időtartam alatt megszüntek.

(4) A kártalanítási kérelmet a jogszabályban a kérelem benyújtására rendszeresített nyomtatványon, a fogvatartás helye szerinti bv. intézetnél, ha pedig az elítélt már szabadult, annál a bv. intézetnél kell benyújtani, ahonnan a szabadítás történt.

39 75/F. $\mathbb{S} *(1)$ bek.: A bv. intézet a kérelmet visszautasítja, ha b) a kérelem nem felel meg a 75/D. $\mathbb{S}$ (2)-(3) bekezdésében meghatározott feltételeknek; d) a kérelmet nem a jogszabályban a kérelem benyújtására rendszeresített nyomtatványon nyújtották be.

$4075 / \mathrm{K} . \mathbb{S}(2)$ bek.: A büntetés-végrehajtási bíró döntése a kérelemhez kötött.

41 75/L. \$: A büntetés-végrehajtási bíró a kérelmet annak a bírósághoz érkezését követően harminc napon belül érdemi vizsgálat nélkül az iratok alapján elutasítja, ha b) a kérelem nem felel meg a 75/D. $\mathbb{S}(2)$-(3) bekezdésében meghatározott feltételeknek; d) a kérelmet nem a jogszabályban a kérelem benyújtására rendszeresített nyomtatványon nyújtották be. 
Ahhoz, hogy a kérdésre megpróbáljuk megadni a választ, célszerủ ismét a jogalkotó végső előterjesztői indokolását elővenni, amely szerint:

„[A] törvényjavaslat átmeneti rendelkezései a törvény hatálybalépésekor szükséges átmeneti szabályokat tartalmazzák. Főszabály szerint a rendelkezéseket a folyamatban lévő eljárásokban is alkalmazni kell, ezek ugyanis eljárásjogi természetüknél fogva a visszaható hatályú jogalkotás tilalmába nem ütköznek. Azokat a helyzeteket, amelyek a kártalanítás jogintézményének a teljes átalakításából következően az egyértelmű jogalkalmazás miatt ettől eltérő kezelést tesznek szükségessé, a törvényjavaslat merev jogszabályi utalással jelöli meg. A kivételek egyrészt azt a célt szolgálják, hogy a szabályozás új elemeinek alkalmazása által ne váljon terhesebbé a már benyújtott kérelmek folytán folyamatban lévő eljárás, másrészt az eljárási határidők számítása szempontjából könnyíti a jogalkalmazói munkát, figyelemmel a folyamatban lévő ügyek mennyiségére."

Álláspontom szerint az indokolásban ellentmondás mutatkozik a körben, hogy egyfelől azt mondja ki, hogy azokat a helyzeteket, amelyek a fószabálytól (az egyszerüsített elbírálás alkalmazása) eltérő kezelést tesznek szükségessé, a jogszabály „merev jogszabályi utalással jelöli meg", másfelől pedig - előbbinek ellentmondva - e merev kivételekről pedig azt írja, hogy az új szabályok által „ne váljon terhesebbé a már benyújtott kérelmek folytán folyamatban lévő eljárás".

A jelenlegi szabályozásban a főszabály tehát az, hogy ha nincs sértett érintve az ügyben, akkor a bv. szerv általi egyszerüsített elbírálásnak van helye. E föszabály alkalmazásának nevesített kivételi esetei között pedig egyik szabály sem azzal kapcsolatos, hogy ezt az egyszerűsített elbírálást alkalmazni kell-e, vagy sem. Bár kétségtelen, hogy az indokolásban kiemelik, hogy az volt a cél, hogy ne váljon terhesebbé az ügyintézés, ugyanakkor az, hogy a 2021. január 1. napja előtt benyújtott kérelmek alapján indult és azóta folyamatban lévő ügyekben nem, csak a 2021. január 1. napját követően benyújtott kérelmek esetében kellene alkalmazni az egyszerűsített elbírálást, nem került a főszabály alóli merev kivételek közé. Márpedig abból nem lehet kiindulni az értelmezéskor, hogy vélelmezhetően nem az volt a jogalkotó szándéka, amit a jogszabály leír.

Fentiekre tekintettel, bár kétségtelen, hogy ez óriási leterheltséget jelentene a bv. intézeteknek, a fenti kérdésre - a bv. szervek számára „sajnálatos” módon - az a válasz adható véleményem szerint, hogy azokat a folyamatban lévő ügyeket, ahol nincs sértetti érintett, vissza kellene küldeni egyszerűsített elbírálás végett a bv. intézeteknek, még akkor is, ha az ilyen kérelmek száma ezres nagyságrendủ is lehet. Az átmeneti rendelkezések ugyanis általánosságban folyamatban lévő ügyekről rendelkeznek attól függetlenül, hogy a kérelem benyújtására 2021. január 1. napja után vagy azt megelőzően került sor - és véleményem szerint tehát a kivételi szabályokból sem vonhatunk le ettől eltérő következtetést. 
További változás, hogy [amellett, hogy a Bv. tv. 50 . $\$(1)$ bekezdés $f$ ) pontja továbbra is úgy rendelkezik, hogy a bv. bíró az ügy érdemében - ide nem értve a bírósági felülvizsgálati eljárást - ügydöntő végzést hoz, amely a Be. 456. $\mathbb{S}(1)$ bekezdése értelmében jogerőre képes határozat] a jogalkotó több helyen egyértelművé tette azon álláspontját, hogy a kártalanítási határozat jogeröre képes. Az, hogy a bv. bírói kártalanítás kapcsán hozott határozatok jogerőre emelkednek vagy csupán véglegessé válnak, a mai napig szakmai viták tárgya ${ }^{42}$ Mindezen viták ellenére olybá tűnik, hogy a jogalkotó „kitart” a jogerőre képesség mellett, amikor a Bv. tv. 50 . $\mathbb{S}(1)$ bekezdés $f)$ pontjának $f a$ ), $f b$ ) és $f c$ ) alpontjaiban is jogerőt említ, továbbá éppen a kártalanítási eljárással összefüggésben a $75 / \mathrm{N}$. $\mathbb{S}(9)$ bekezdése kifejezetten akképp rendelkezik, hogy a büntetés-végrehajtási bíró a jogerős határozatot a jogerőre emelkedést követő 15 napon belül megküldi az igazságügyért felelős miniszternek. A kifizetési szabályok körében ugyancsak ezt megismétli, amikor a 75/O. $\mathbb{S}$ (1) bekezdése kimondja, hogy a kártalanítással összefüggő kifizetés iránt az igazságügyért felelős miniszter intézkedik a bv. intézet határozatának vagy a büntetés-végrehajtási bíró jogerős ügydöntő végzésének az igazságügyért felelős miniszterhez történő érkezésétől számított a) 90 napon belül, b) a 75/R. $\mathbb{S}(1)$ bekezdése szerinti esetben 120 napon belül.

\section{3. Összegző megállapítások, jövőkép}

Álláspontom szerint a jogalkotó az „ígéretének” - amely szerint a sértettekkel kapcsolatos szabályozás tekintetében nem korlátozódik majd kizárólag a börtönzsúfoltság miatti kártalanítási eljárás reformjára, hanem átfogó módon (tehát nem csupán a szabadságvesztés büntetéssel járó bűncselekmények sértettjei tekintetében) fejleszteni kívánja az áldozatok segítésének, igényérvényesítésének jogszabályi feltételeit, hanem ennek érdekében általában a sértettek kiemelt támogatását szolgáló szabályozási megoldásokat jelentenek majd - nem feltétlenül tett eleget az új szabályozás bevezetésével.

Ugyanis a korábban hatályban volt szabályok is előírták, hogy a sértetti érdekek érvényesítése érdekében a büntetés-végrehajtási bírónak, ha az érdemi elbírálás nem kizárt, a döntés meghozatalát megelőzően a fogvatartás alapjául szolgáló büntetőügy sértetti követelések figyelembevételéről gondoskodnia kell, és a büncselekménnyel okozott kár vagy sérelem megtérülése körülményeinek vizsgálatát el kell végeznie. Ennek eredményeképp a korábbi szabályok szerint is az volt a bv. bíró kötelezettsége, hogy a határozatában rendelkezzen az alapvető jogokat sértő elhelyezési körülmények miatt megállapított kártalanítás összegéből a még fennálló követelés erejéig a polgári jogi igény, illetve a bủncselekmény miatt megállapított kártérítés vagy sérelemdíj jogosultja javára történő kifizetésről.

42 Lásd 2/2015. büntető jogegységi határozat; Kúria Bfv.II.1.326/2018.szám alatti döntés; BH2020. 360. szám alatt megjelent, a Kúria Bfv. I. 573/2020. szám alatti döntés; 3087/2020. (IV. 23.) $\mathrm{AB}$ határozat [38] bekezdése szerint levezetett értelmezések. 
A kifizetésről való rendelkezés - csak úgy, mint a korábbi szabályok szerint - továbbra is több feltételhez kötött, így ahhoz is, hogy a sérelem teljesítésére a megítélés ellenére az elítélt részéről még nem, vagy csak részben került sor, és ahhoz is, hogy a bíró az elítélt vagy védője ilyen irányú védekezését vizsgálva megállapította, hogy a Ptk. szerinti általános elévülési idő még nem telt el.

Az elévülés vizsgálatával kapcsolatban az új szabályok egyértelműsítik azt, hogy az elévülési idő figyelembevétele kapcsán a bűncselekménnyel okozott károk (nem vagyoni sérelmek) tekintetében nem feltétlenül az általános ötéves elévülési idő az irányadó. A Ptk. 6:533. $\mathbb{\$}(1)$ bekezdése értelmében a kártérítésre az elévülés szabályait azzal az eltéréssel kell alkalmazni, hogy büncselekménnyel okozott kár esetén a követelés öt éven túl sem évül el mindaddig, amíg a büncselekmény büntethetősége el nem évül. Azonban az továbbra is problémát okozhat a jogalkalmazásban, hogy ha az elítélt elévülésre hivatkozik, akkor szükséges lehet annak vizsgálata is, hogy az elévülési idő megszakadt-e. Erre azonban tárgyaláson megszokott „mélységü” bizonyítást felvenni nem lehetséges az iratok alapján történő elbírálás keretében, holott az előfordulhat, hogy a sértett akár okirattal tudja bizonyítani azt, hogy az elévülés megszakadt. Álláspontom szerint tehát abban az esetben, ha az elítélt elévülésre hivatkozik, nem mellőzhető a sértett felhívása, hogy amennyiben elévülést megszakító körülményre kíván hivatkozni ezzel szemben, úgy csatoljon ezt alátámasztó iratot. Amennyiben azonban ilyenre nem kerül sor, akkor értelemszerủen úgy kell tekinteni, mintha az elévülés bekövetkezett volna - ha valóban eltelt az elévülési idő.

Ugyanakkor az valóban a sértettek érdekét szolgáló újítás, hogy a kártalanítás megítéléséről szóló határozatban nem a kifizetésről, hanem a polgári jogi igény, illetve a bűncselekmény miatt megítélt kártérítés vagy sérelemdíj jogosultjának a még fennálló követelése erejéig a kártalanításból történő levonásra való jogosultságát kell megállapítani, és a megállapításnak már nem feltétele, hogy a követelés behajtása iránt korábban nem indult végrehajtási eljárás. ${ }^{43}$ További „előremutató” szabályként lehet értékelni a sértettek szemszögéből azt az új rendelkezést is, amely szerint már egységesen, minden más végrehajtás alatt álló követeléssel együtt az igazságügyért felelős miniszter kifizetést megelőző feladatai körében vizsgálandó, hogy az elítélt által nem teljesített, a sértett javára megítélt polgári jogi igény, illetve a bűncselekmény miatt megállapított kártérítés vagy sérelemdíj behajtása iránt indult-e végrehajtási eljárás, mellőzhetővé válik a korábban hatályos szabályozásból az feladat, hogy a kártalanításról hozott döntést megelőzően ezt a körülményt a Magyar Végrehajtói Kar megkeresése útján vizsgálja. ${ }^{44}$

A korábban hatályos eljárási rendszerrel egyezően az új szabályozás átvette, ugyanakkor ki is egészítette azt a kielégítési rangsort, amely arra az esetre szól, ha a kártalanításként megítélt összeg nem elégséges valamennyi levonható követelés kielégítésére.

43 Bár ezzel ellentétben a 75/N. \$-hoz füzött végső előterjesztői indokolásban az szerepel, hogy a kifizetésről szóló rendelkezés feltételei közül az egyik továbbra is az, hogy a követelések behajtása iránt végrehajtási eljárás nem indult. 
A kielégítési rangsorban első helyen a gyermektartásdíj iránti követelés áll továbbra is. Ha gyermektartásdíj címén nincs fennálló követelés vagy annak levonását követően a kártalanítási összegből van maradvány, azt a bűncselekmény miatt megítélt polgári jogi igény, illetve a bűncselekmény miatt megítélt kártérítés vagy sérelemdíj kifizetésére kell fordítani. A jogosultságot a büntetés-végrehajtási bíró határozata, illetve ha a behajtás iránt már van folyamatban végrehajtási eljárás, a végrehajtói követelésfoglalás alapozza meg. Az új szabályok általi egyik lényegi módosítás éppen ehhez kapcsolódóan ebben a sorban figyelembe veendő sértetti követeléseket a korábban hatályos szabályozáshoz képest kiterjesztette. Elöírja ugyanis a terhelt által elkövetett, a fogvatartás alapjául szolgáló büntetőügyön kívüli bármely más büncselekmény miatt megítélt sértetti követelések levonását is, ha azzal kapcsolatban a végrehajtó követelésfoglalást foganatosított. Ezeket követően még a kifizetést megelőzően levonható a fenti jogcímen túli, a bírósági végrehajtó által foganatosított bármely végrehajtás alatt álló követelés.

Az új szabályozás egyik további lényegesnek mondható újítása az is, hogy megteremtette annak a lehetőségét, hogy a végrehajtási eljárás hatálya alatt nem álló, a kifizetést megelőzően nem levonható egyéb követelések esetén is mód nyíljon arra, hogy azok esetében is - hasonlóan bármely más, az érintett adóshoz jutó pénzöszszeghez -, az eljáró szervek intézkedhessenek a behajtás iránt. Ennek megfelelően lehetőség nyílik arra is, hogy az adótartozásokon és az adók módjára behajtandó köztartozásokon túl számos büntetőeljárással összefüggésben megfizetendő tartozások, így a pénzbüntetés, bünügyi költség, rendbírság, vagyonelkobzás stb. behajtása ${ }^{45}$ érdekében intézkedés történhessen. ${ }^{46}$

A jogalkotó azon ígéretével összefüggésben, hogy az új szabályok hatékonyabban fogják szolgálni a sértettek követeléseinek kielégítését, rá kell világítani arra is, hogy az elmúlt évek statisztikai adatai azt mutatják, hogy a bv. intézetek átlagtelítettsége a következők szerint alakult: 2016-ban 131\%, 2017-ben 129\%, 2018-ban 122\%, 2019-ben pedig $112 \%$ volt. ${ }^{47}$

A börtönzsúfoltsági kártalanításokkal kapcsolatos visszaélések megszüntetése érdekében szükséges haladéktalan intézkedésekről szóló 2020. évi IV. törvény 2. \$-ában az Országgyủlés felhívta a Kormányt, hogy a börtönzsúfoltság megszüntetése érdekében 2020. szeptember 30-áig biztosítsa, hogy a büntetés-végrehajtási intézetek átlagos kihasználtsága ne haladja meg a teljes (száz százalékos) kihasználtságot.

45 Az adóvégrehajtási eljárásról szóló törvény alapján 2018. január 1-jétől az állami adó- és vámhatóság általános végrehajtási hatósággá vált: az adók módjára behajtandó köztartozásokon túl számos egyéb köztartozás végrehajtását is a NAV foganatosítja, továbbá 2019. január 1-jétől feladata lett az állami és igazságügyi követelések, valamint az igazságszolgáltatás gyakorlása során megállapított vagyoni jellegủ joghátrányok végrehajtása is.

46 Erre azonban csak akkor kerülhet sor, ha a kártalanítási összegből való levonások után marad fenn a kérelmező részére kifizetendő összeg. Ilyen esetben a NAV az igazságügyért felelős minisztertől kapott jelzés alapján végezhet végrehajtási cselekményt. Bv. tv. 75/R. \$.

47 Feleky István: A kártalanítás és a feltételes szabadságra bocsátás feltételei a büntetés-végrehajtási bírói gyakorlatban. Forum Sententiarum Curiae, (2020), 1. 4. hivatkozza Börtönstatisztikai Szemle, 5. (2019), 1. 7. 
A T/9241. számú törvényjavaslatban rögzített, a 2. \$-hoz füzött részletes indokolás szerint: „[A] Kormány célja nem a tüneti kezelés, hanem a teljes problémakör megoldása, azaz a büntetés-végrehajtási intézmények túlzsúfoltságának - a kártalanítás alapvető jogalapjának - megszüntetése."

Erre tekintettel tehát kijelenthetjük, hogy a sértettek igényeinek kielégítésére nem lesz alkalmas a kártalanítási eljárás abban az esetben, ha a túlzsúfoltság teljes megszűnése esetében nem is fog várhatóan sor kerülni az elítélteknek kártalanítás megállapítására. Tehát önmagában ezen új szabályok a sértetteknek megítélt polgári jogi igények kielégítését érdemben nem fogják előmozdítani. A sértetteknek tehát továbbra is végrehajtási eljárást kell kezdeményezniük az elítéltekkel szemben, amely eljárás sikerességének az esélye az esetek túlnyomó többségében kétséges.

Ezzel párhuzamosan azonban az a prognózis vetíthető előre, hogy a polgári ügyszakban ügyérkezés-növekedés várható, amelynek kiindulópontja, hogy a bv. bírói kártalanítás, illetőleg a további kártérítés és sérelemdíj iránti igény jogalapja nem azonos: ${ }^{48}$ a bv. bírói kártalanítás jogalapja a Bv. tv., míg a további kártérítés és sérelemdíj iránti igény jogalapja a Ptk. által meghatározott feltételrendszer. Kérdéses, hogy az alapvető jogokat sértő elhelyezési körülményekre alapozott igényről kizárólag a bv. bíró dönthet-e, avagy megválasztható-e, hogy a bv. bíró vagy a polgári bíróság adjon elégtételt. Abból azonban, hogy a kártalanítás jogalapját is a Bv. tv. határozza meg, az látszik következni, hogy igényérvényesítési fórumkényszerről, vagyis (egészében) sui generis jogintézményről van szó, ${ }^{49} \mathrm{~s}$ ekként az adott igény elbírálása kizárólagos bv. bírói hatáskörbe tartozik. Másként fogalmazva, nem kerülhető meg a bv. bírói eljárás, így nincs törvényes lehetőség az alapvető jogokat sértő elhelyezési körülmények miatt közvetlenül a polgári bírósághoz fordulni. ${ }^{50}$

A Bvtv. 75/B. $\mathbb{S}(1)$ bekezdése szerint kártalanítás jár az elítéltnek a fogvatartása során a jogszabályban előírt élettér biztositásának hiánya és az ehhez esetlegesen kapcsolódó más, a kínzás, kegyetlen, embertelen vagy megalázó bánásmód tilalmába ütköző elhelyezési körülmény, különösen az illemhely elkülönítésének a hiánya, a nem megfelelő szellőztetés, világítás, fütés vagy rovarirtás (a továbbiakban együtt: alapvető jogokat sértő elhelyezési körülmények) által előidézett sérelem miatt.

Tehát ha az élettér biztosítva van, akkor a Bv. tv. alapján történő kártalanítási eljárásnak sincs helye, hanem akkor előtérbe kerülhet a polgári peres eljárás.

A kártalanítás jogintézménye bv. bírói alkalmazásának kezdetekor felmerült azon jogértelmezési vita, hogy az egyéb elhelyezési körülmény - így például az elkülönített illemhely hiánya, a rovarcsípések okozta sérelmek stb. - önmagában megalapozhat-e kártalanítást. Egységesült a joggyakorlat abban, hogy a bv. bírák kivétel nélkül utaltak arra, hogy a 2016. évi CX. törvény 22. \$-ához kapcsolódó indokolás, valamint a Kúria

48 „[A]z alapvető jogot sértő elhelyezési körülmények kártalanítási szabályai nem hozhatók összefüggésbe a kártérítési eljárás szabályaival, ezekre vonatkozóan a jogalkotó eltérő szabályozást alkalmazott." 3254/2019. (X. 30.) AB határozat, indokolás [30]. 
2018. március 7. napján kelt joggyakorlat-elemző összefoglaló véleményének 45. oldalán kifejtettekből is arra tehető megállapítás, hogy a Bv. tv. szerinti kártalanítás iránti eljárásban a megfelelő „élettér” biztosítása esetén az egyéb elhelyezési körülmények közömbösek, azok csak a túlzsúfoltság esetén vehetőek figyelembe az elszenvedett jogsérelem súlyának megítélésekor.

A polgári perekkel kapcsolatban tehát itt kap szerepet a Bv. tv. 2020. december 31. napjáig hatályos $10 / \mathrm{A} . \mathbb{\$}(2)$ bekezdése, 2021 . január 1 . napjától hatályos $75 / \mathrm{B}$. $\mathbb{S}$ (4) bekezdése. Ugyanis a bv. eljárásokban azt a következtetést vonták le, hogy

„[a] megfelelő »élettér« biztosítása mellett az esetlegesen mutatkozó egyéb elhelyezési körülmények terén mutatkozó hiányosságok nem a kártalanítási eljárás során, hanem egyéb törvényes úton, polgári bíróság előtt érvényesíthetőek, mint ahogyan erre a Bv. tv. 10/A. $\mathbb{\$}(2)$ bekezdése is utal." ${ }^{1}$

Kialakult tehát egy olyan értelmezés, ${ }^{52}$ amely szerint az elítélt vagy egyéb jogcímen fogva tartott (kérelmező) a bv. bíróság által, már a kártalanítási eljárásban elbírált alapvető jogokat sértő elhelyezési körülmények miatt igényt érvényesíthet a polgári bíróság elött, ha a részére megítélt kártalanítási összeg „nem megfelelő, nem elegendő”.

Ezzel azonban a következő ellentétes álláspont rajzolódik ki a polgári ügyszakosok részéről. Ha a „meghatározott jogcímen” magát a kártalanítást értjük, akkor a rendelkezés értelmezhetetlen, érthetetlen, ugyanis az lefordítva így hangzana: kártalanítás címén további kártérítésnek vagy sérelemdíjnak helye nincs, de a fél jogosult az ezt meghaladó igényét polgári bíróság előtt érvényesíteni. Ennek a rendelkezésnek csak akkor van „értelme”, ha az itt írt „meghatározott jogcímen” kifejezésen nem pusztán a kártalanítást, hanem a kínzás, a kegyetlen, embertelen vagy megalázó bánásmód tilalmába ütköző elhelyezési körülmények által előidézett sérelmeket értik. A Bv. tv. 10/A. $\mathbb{S}$-hoz füzött kommentári magyarázatban is kifejezetten szerepel, hogy

„a kártalanítási összeg megítélése és kifizetése után sérelemdíjnak, vagy kártérítésnek helye nincs. Ennek oka, hogy a kártalanítási összeg alkalmas arra, hogy kompenzálja az alapvető jogokat sértő elhelyezési körülmények miatti kárigényeket”.

Ez a kommentárbeli értelmezés áll összhangban a jogalkotó - vélelmezhető - céljával is, mivel ezzel a jogszabállyal akart megfelelő és egyszerűbb reparációt nyújtani az ilyen jellegű sérelmeket elszenvedő kérelmezők számára. Ha pedig attól eltérő

51 Debreceni Törvényszék 1.Bpkf.7/2019/4. szám.

52 Ezt jelenítik meg a Fővárosi Törvényszék Büntető Kollégiumának összefoglaló anyaga (az alapvető jogokat sértő elhelyezési körülményekből eredő sérelmen alapuló kártalanítási eljárás szabályairól) 12. oldalán foglaltak is: [N]em vitatva azt, hogy egyéb elhelyezési körülmény is megvalósíthatja a kínzó, embertelen, megalázó bánásmódot, de az ilyen módon elszenvedett jogsérelem vagyoni kompenzálásra nem a kártalanitási eljárás során, hanem egyéb törvényes úton, polgári bíróság elött van lehetöség [...]." 
következtetésre jutnánk, hogy a „többletigény” polgári perbeli érvényesítésének nincs helye, és azt állapítanánk meg, hogy a fél a megítélt kártalanítási összegen felül az elhelyezési körülményeket sérelmezve érvényesíthet polgári bíróság előtt kártérítési, illetőleg sérelemdíj iránti követelést, akkor ezzel azt erősítenénk, hogy a jogalkotó nem érte el a célját, következésképpen nemcsak odáig juthatnánk el, hogy a polgári bíróság előtti igényérvényesítésnek van helye, hanem akár újból az EJEB-hez fordulás joga is felvethető.

Tehát nem megengedhető-e a polgári perindítás, még akkor sem, ha a Bv. tv. 10/A. $\mathbb{\$}(1)$ bekezdésében [2021. jan. 1-től 75/B. $\mathbb{S}(1)$ bekezdés] szereplő, oda tartozó konkrét elhelyezési körülményeket jelöl meg a felperes, de ezzel másik személyiségi jogának megsértését állítja. E vélemény szerint tehát csak olyan pénzbeli marasztalásra irányuló jogvitákat dönthetnek el a polgári bíróságok, amelyek nem az alapvető elhelyezési körülményekkel állnak összefüggésben, hanem például a fogvatartás alatti orvosi kezelésből, az őrök viselkedéséből eredő sérelmek miatt. ${ }^{53}$ Ha viszont az alapvető jogokat sértő elhelyezési körülmények miatt a fogvatartott a személyiségi jogsértés objektív szankcióit kívánja érvényesíteni, attól nem zárható el, azt az általános szabályoknak megfelelően a polgári bíróság előtt érvényesítheti - tehát kizárólag a felróhatóságtól független, objektív szankciókról való döntés tartozik ide. ${ }^{54}$

Ennek megfelelően, ha valóban elő́ll az a helyzet, hogy teljesen megszünnek a bv. intézetek túlzsúfoltsági körülményei, akkor a következőkkel kell szembesülni. A bv. bírói értelmezés szerint tehát, ha nem állapítható meg a túlzsúfoltság, akkor nem vizsgálják az egyéb elhelyezési körülményeket. Azonban, ha a fogvatartottak mégis úgy érzik, hogy sérelmes helyzetüket „reparálni” kell, akkor is először kártalanítási kérelmet kell előterjeszteniük, ha még tisztában is vannak azzal, hogy nem túlzsúfolt körülmények között voltak elhelyezve - mert ezt a „jogorvoslati” lehetőséget ki kell meríteniük. ${ }^{55} \mathrm{Ez}$ egyértelműen felesleges adminisztratív terhet ró a bv. intézetekre és a bv. bíróságokra. Ha azonban azt az értelmezést vesszük alapul, hogy pénzbeli követelést polgári bíróság előtt nem, csak a bv. bíróságok előtt lehet támasztani, attól bizonyosan elesnek a kérelmezők, ha nem áll fenn a túlzsúfoltság. Álláspontom szerint tehát mindez ahhoz az aggályos helyzethez vezet, hogy a kérelmezök az egyéb elhelyezési körülményeik miatti sérelmek okozta személyiségi jogaik megsértése miatt igényeik pénzbeli kompenzálásra irányuló érvényesitésétól teljesen el lesznek zárva, a birósághoz fordulás joga kizáródik. „Faramuci” helyzetbe kerülnek tehát a fogvatartottak, mert sem a Bv. tv. szerinti kártalanítási eljárásban, sem pedig a Pp.-n, illetve Ptk.-n alapuló személyiségi jogok megsértése iránt indított perben érdemi jogorvos-

53 Meg kell jegyezni azonban, hogy e körben akkor mindenekelőtt azt kell tisztázni, hogy mi minősül elhelyezési körülménynek, vagyis arra is választ kell adni, hogy a Bv. tv. 10/A. $\mathbb{\$}$ (1) bekezdésében [2021. jan. 1-től 75/B. $\mathbb{S}(1)$ bekezdés] szereplő felsorolás taxatív, kimerítő jellegű-e, vagy példálózó és a gyakorlatnak kell kimunkálnia, hogy mik tartoznak ebbe a körbe.

54 Kúria (2018): i. m. 11.

55 Lásd BDT 2018.3850. 
latra nem biztos, hogy számíthatnak. Ez pedig korántsem biztos, hogy „kiállna egy EJEB előtti próbát”.

Fentiek alapján azt a végkövetkeztetési prognózist is levonhatjuk, hogy amenynyiben a bv. intézetek telítettsége $100 \%$ alá süllyed, a fogva tartott kérelmezőknek az alapvető jogokat sértő elhelyezési körülményeik vélt sérelme esetén ugyan ki kell meríteniük a Bv. tv. szerinti jogorvoslati formát - amely így felesleges terhet ró a bv. intézetekre és a bv. bírókra -, azonban mivel jogérvényesítési lehetőségeiket nem lehet korlátozni, vélhetően mégis ismételten nagyobb számban polgári bírósághoz fognak fordulni, így ott ügyérkezés-növekményre lehet számítani. Úgy vélem, hogy már csak azon megfontolásból kifolyólag is inkább polgári bírósághoz fognak fordulni az elítéltek, hogy mivel a Bv. tv. szerint megítélt kártalanítási összegből most már gyakorlatilag minden egyéb követelés is (például pénzbüntetés, bünügyi költség is) levonható, a kérelmezőknek az fog az érdekükben állni mégis, hogy akár a hosszasabb polgári per végén marasztalják az államot, mert e marasztalási összegből ilyen levonásokra nincs lehetőség.

Jelen tanulmány végén gondolatébresztő jelleggel pedig azt a polgári bíróságok elé álló kihívást vetem fel, hogy amennyiben a bv. eljárásban érdemi tényállásbeli megállapításokra kerül sor, akkor azt a polgári bíróságok a Pp. 270. \$-ában (más eljárásban felvett bizonyítás eredményének felhasználása) foglaltak fényében hogyan és miként veszik figyelembe.

\section{Irodalomjegyzék}

Bagossy Mária: Kártalanítás az alapvető jogokat sértő elhelyezési körülmények miatt. In Mailáth György Tudományos Pályázat 2018. Dijazott dolgozatok. Budapest, Országos Bírósági Hivatal, 2018. 252-293. Online: https://birosag.hu/sites/default/files/2019-03/dijazott_dolgozatok_mailath_gyorgy_tudomanyos_palyazat_2018.pdf

Boda Zoltán: Az alapvető jogokat sértő elhelyezési körülmények miatt indított kártalanítás aktuális jogértelmezési kérdései. Acta Humana, 8. (2020), 1. 7-23. Online: https://doi.org/10.32566/ ah.2020.1.1

Boda Zoltán: Az alapvető jogokat sértő elhelyezési körülmények miatti kártalanítási eljárás és a személyiségi jogsértés miatt indult polgári per konkurálása. Acta Universitatis Szegediensis FORVM: Publicationes Doctorandorum Juridicorum, 11. (2021). 5-22. Online: http://acta.bibl.u-szeged. hu/73165/

Feleky István: A kártalanítás és a feltételes szabadságra bocsátás feltételei a büntetés-végrehajtási bírói gyakorlatban. Forum Sententiarum Curiae, (2020), 1. 4-9. Online: https://kuria-birosag. $\mathrm{hu} /$ sites/default/files/fsc_tanulmany/drfeleky_0.pdf

Juhász Andrea Erika: Varga és mások kontra Magyarország - az EJEB döntése. Jogászvilág, 2015. április 17. Online: https://jogaszvilag.hu/vilagjogasz/varga-es-masok-kontra-magyarorszag-azejeb-dontese/

Juhász Andrea Erika: A kínzás, az embertelen, a megalázó bánásmód tilalma a fogvatartottakkal szemben. Doktori értekezés. Szeged, Szegedi Tudományegyetem Állam- és Jogtudományi Kar Doktori Iskola, 2016. Online: http://doktori.bibl.u-szeged.hu/id/eprint/3140/ 
Kúria: Emlékeztető, amely felvételre került az Új Ptk. Jogegységi Csoportok 2018. október 5-ei üléséről (2018). Online: https://kuria-birosag.hu/sites/default/files/konz_testulet/emlekezteto_2018_10_05.pdf

Nagy Zsuzsanna - Boda Zoltán: Az alapvető jogokat sértő elhelyezési körülmények miatti kártalanítás új szabályai, visszatekintés a panasz jogintézményére. Büntetőjogi Szemle, (2020), 2. 99112. Online: https://ujbtk.hu/wp-content/uploads/lapszam/BJSZ_202002_99-112o_NagyZsuzsanna_BodaZoltan.pdf

Szemesi Sándor: Az emberi jogok európai őrének új fegyvere: a pilot judgement eljárás a strasbourgi bíróság gyakorlatában. Jog-Állam-Politika, 5. (2013), 4. 47-63. Online: https://dfk-online.sze. hu/images/J\%C3\%81P/2013/4/szemesi.pdf

\section{Bírósági határozatok}

Debreceni Törvényszék 1.Bpkf.7/2019/4.

Kúria Bkk.I.926/2017/5.

Kúria Bt.I.1199/2019/5.

\section{EJEB határozatok}

Domján kontra Magyarország, EJEB, 2017. november 14-i határozat (ügyszám: 5433/17)

Dougoz kontra Görögország, EJEB, 2001. március 6-i ítélet (ügyszám: 40907/98)

Latak kontra Lengyelország, EJEB, 2010. október 12-i elfogadhatatlansági döntés (ügyszám: 52070/08)

Varga és mások kontra Magyarország, EJEB, 2015. március 10-i ítélet (ügyszámok: 14097/12, 45135/12, 73712/12, 34001/13, 44055/13 és 64586/13) 